\title{
MODEL BELIEF ADJUSTMENT DALAM PENGAMBILAN KEPUTUSAN INVESTASI BERDASARKAN INFORMASI NONAKUNTANSI
}

\author{
Anita Angraeni \\ STIE Perbanas Surabaya \\ Luciana Spica Almilia \\ STIE Perbanas Surabaya \\ lucy@perbanas.ac.id
}

\begin{abstract}
The purpose of this study is to examine is there any difference on investment decision making among participant that received good news information followed by bad news compared with participant that received bad news information followed by good news on the SbS and EoS information disclosure pattern, also long and short information series. The experiment design in this study is $2 \times 2 \times 2$ mix design subject, which is the information disclosure pattern (step by Step and End of Sequence), information order (good news followed by bad news), and information series (long and short infomation series). The Independent Sample t-test used to examined the research hypothesis. The amount of participant involved on this study are 96 college students in STIE Perbanas Surabaya in Accountant and Management major. The result show that there were difference on investment decision making among participant that received good news information followed by bad news compared with participant that received bad news information followed by good news on the SbS information disclosure pattern and long information series and also occurs recency effect.
\end{abstract}

Keywords: step by step, end of sequence, investment decision, nonaccountant information.

\begin{abstract}
ABSTRAK
Tujuan penelitian ini adalah menguji perbedaan keputusan investasi antara partisipan yang menerima informasi good news diikuti bad news dibandingkan dengan partisipan yang menerima informasi bad news diikuti good news, baik pada pola penyajian SbS maupun EoS dan seri informasi panjang dan pendek. Penelitian ini menggunakan metoda eksperimen $2 \times 2 \times 2$ mix design, yaitu pola penyajian (step by step dan end of sequence) dan urutan informasi (good news diikuti bad news dan bad news diikuti good news) dan seri informasi (informasi panjang dan informasi pendek). Independent Sample t test digunakan untuk menguji hipotesis penelitian. Jumlah partisipan dalam penelitian ini adalah 96 mahasiswa Akuntansi dan Manajemen STIE Perbanas Surabaya. Hasil penelitian menunjukkan bahwa terdapat perbedaan dalam pengambilan keputusan investasi dan terjadi recency effect bagi partisipan yang menerima good news diikuti bad news dibandingkan dengan
\end{abstract}


partisipan yang menerima informasi bad news diikuti bad news pada pola penyajian SbS dan seri informasi panjang.

Kata Kunci : step by step, end of sequence, keputusan investasi, informasi non akuntan.

\section{PENDAHULUAN}

Pasar modal memiliki peranan yang cukup penting dalam dunia perekonomian saat ini, dikarenakan banyak para investor yang memanfaatkan pasar modal sebagai media untuk berinvestasi. Pergerakan harga saham yang fluktuatif menjadi salah satu risiko bagi para investor. Akan tetapi pergerakan harga saham yang fluktuatif juga dapat mendatangkan keuntungan bagi para investor. Oleh karena itu, investasi pada saham disebut sebagai bisnis yang berisiko tinggi.

Ketika investor akan mengambil keputusan untuk berinvestasi pada saham, informasi utama yang harus diketahui oleh investor adalah informasi tentang perusahaan yang akan ditanami modal. Informasi tersebut tak hanya mengenai informasi akuntansi melainkan informasi nonakuntansi juga penting untuk diketahui oleh investor. Para investor juga perlu memperhatikan informasi nonakuntansi yang disajikan oleh perusahaan, karena informasi nonakuntansi tidak hanya mengenai kinerja keuangan dari perusahaan saja melainkan informasi tentang prospek perusahaan dimasa datang dikarenakan dalam menganalisis harga saham para investor seringkali mengabaikan informasi tersebut.

Keberagaman dari pengungkapan informasi nampak pada laporan tahunan perusahaan. Berdasarkan hasil pengamatan pada 16 September 2015 yang dilihat dari situs resmi www.idx.co.id, PT Gudang Garam Tbk menyajikan laporan tahunannya pada tahun 2015 memiliki urutan informasi yang berbeda dengan PT Indofood CBP Sukses Makmur Tbk yang melaporkan laporan tahunannya pada tahun 2015. Berdasarkan perbedaan tersebut bahwa terjadi perbedaan penyajian informasi pada laporan tahunan perusahaan yang diduga berdampak pada pengambilan keputusan investasi perusahaan.

Ketika investor melakukan pertimbangan dalam pengambilan keputusan, investor cenderung memulai dengan keyakinan awal kemudian melakukan revisi atas keyakinan tersebut. Revisi atas keyakinan tersebut didasarkan pada kekuatan dan arah dari bukti yang telah didapat. Akan tetapi seringkali pertimbangan atas revisi keyakinan tersebut bukanlah esensi ataupun substansi dari bukti melainkan urutan dari bukti.

Terdapat beberapa faktor yang mempengaruhi keputusan investasi. Wahyuni dan Hartono (2012) menguji faktor informasi yang diperoleh sebelumnya oleh investor mempengaruhi keputusan investasi. Penelitian lain dilakukan oleh Alvia dan Sulistiwan (2009) bertujuan untuk mengetahui adanya efek resensi pada informasi gabungan pada pola penyajian sekuensial, dan mengetahui efek pengetahuan dari analisis teknikal dalam pengambilan keputusan investasi. Hasil penelitian Alvia dan 
Sulistiwan (2009) menunjukkan bahwa terdapat efek kekinian atau resensi dalam pengambilan keputusan investasi pada saham ketika informasi nonakuntansi disajikan secara berurutan yang masing-masing bermuatan positif dan negatif. Pada penelitian Alvia dan Sulistiwan (2009) juga menunjukkan terjadinya perbedaan keputusan berbasis analisis teknis antara kelompok yang mendapatkan pengetahuan mengenai analisis teknikal dengan kelompok yang tidak mendapatkan pengetahuan mengenai analisis teknikal, namun tidak terdapat perbedaan keputusan pada kelompok yang tidak mendapatkan pengetahuan. Almilia dan Wulanditya (2016) memberikan bukti bahwa individu yang memiliki tingkat kepercayaan yang tinggi cenderung mengabaikan informasi yang tersedia, hal ini berdampak bahwa individu dengan tingkat kepercayaan yang tinggi terhindar dari efek urutan.

Penelitian mengenai Model Belief Adjustment dalam pengambilan keputusan telah banyak dilakukan oleh peneliti sebelumnya. Almilia dan Supriyadi (2013a) menyatakan bahwa terdapat pengaruh order effect dalam pengambilan keputusan investasi, yaitu recency effect, dan tidak adanya pengaruh recency effect pada informasi yang disajikan dengan pola pengungkapan end of sequence. Penelitian ini didasarkan pada konsep teori Model Belief Adjustment Hogart dan Einhorn (1992). Teori ini memprediksi bahwa ketika dua informasi memiliki muatan konten yang berbeda yakni informasi bersifat campuran (good news-bad news) dan pola penyajian secara berurutan maka individu cenderung melakukan revisi atas keyakinan awal dari suatu keputusan. Sedangkan dalam kondisi tertentu individu cenderung membobot informasi terkini lebih penting daripada informasi sebelumnya atau biasa disebut dengan efek resensi.

Pola penyajian informasi yang diuji pada penelitian ini yaitu $S b S$ dan EoS. Pola penyajian $S b S$ adalah pola penyajian informasi berdasarkan informasi yang disajikan secara berurutan. Sedangkan pola penyajian EoS adalah pola penyajian informasi berdasarkan informasi yang disajikan secara keseluruhannya diperoleh saat itu juga. Kompleksitas seri informasi yang diuji pada penelitian ini yaitu informasi seri panjang dan informasi seri pendek. Panjangnya seri bukti informasi adalah menunjukkan jumlah bukti yang dievaluasi. Jumlah bukti informasi dapat diklasifikasikan sebagai seri informasi pendek apabila terdiri dari 2 sampai 12 bukti informasi, dan dapat diklasifikasikan sebagai bukti informasi seri panjang apabila terdiri lebih dari 17 bukti informasi. Pada penelitian ini menggunakan informasi seri pendek sejumlah 8 informasi dan seri panjang sejumlah 18 informasi. Informasi nonakuntansi pada penelitian ini mencakup informasi tentang Good Corporate Governance dan Corporate Social Responsibility.

Partisipan pada penelitian ini yaitu Mahasiswa jurusan S1 Akuntansi dan S1 Manajemen di STIE Perbanas Surabaya yang sedang dan/atau telah menempuh mata kuliah Analisa Laporan Keuangan dan Manajemen Investasi Pasar Modal atau Manajemen Investasi Portofolio. Penelitian ini bertujuan untuk mengetahui perbedaan pengambilan keputusan investasi pada pola penyajian informasi (step by 
step dan end of sequence), urutan informasi (good news diikuti bad news dan bad news diikuti good news), dan seri informasi (seri informasi panjang dan seri informasi pendek) pada informasi nonakuntansi.

Manfaat penelitian yang dapat diperoleh adalah sebagai berikut: bagi pembaca, diharapkan bisa ditambahkan sebagai referensi bacaan untuk penelitian selanjutnya mengenai pengambilan keputusan investasi menggunakan riset eksperimen, bagi perusahaan penelitian ini diharapkan dapat menentukan kebijakan yang diambil untuk menarik minat para investor agar dapat menanamkan modalnya di perusahaan serta dapat memberikan manfaat bagi perusahaan dalam menyampaikan informasi yang relevan agar dapat menarik minat para calon investor. Manfaat penelitian bagi akademisi, diharapkan dapat memberikan kontribusi serta referensi bagi peneliti sejenis maupun civitas akademika lainnya untuk studi selanjutnya dalam mengembangkan ilmu pengetahuan untuk kemajuan dan perkembangan dunia pendidikan.

\section{KAJIAN PUSTAKA DAN PERUMUSAN HIPOTESIS}

\section{Model Belief Adjustment}

Hogarth dan Einhorn (1992) mengajukan dan menguji teori tentang model keyakinan yang kemudian biasa disebut model Belief Adjustment. Model ini didasarkan pada asumsi bahwa ketika seseorang memproses informasi secara keseluruhan dan memiliki keterbatasan mengenai kapasitas memori, individu cenderung mengubah keyakinannya melalui proses penyesuaian. Mereka menyatakan ketika individu memperoleh bukti baru maka mereka merevisi kembali keyakinan dengan proses penyesuaian.

Model Belief Adjustment yang dikembangkan oleh Hogarth dan Einhorn (1992) telah mempertimbangkan tiga karakteristik yaitu: arah, kekuatan, dan tipe. Pada penelitian Ashton dan Ashton (1988) menyatakan bahwa model Belief Adjustment telah mempertimbangkan dua karakteristik penting yang diabaikan dalam Bayes' Theorem, yaitu pola penyajian informasi dan urutan informasi. Ashton dan Ashton (1988) menyatakan bahwa model belief adjustment yang dikembangkan oleh Hogarth dan Einhorn (1992) telah merepresentasikan sikap individu terhadap bukti. Pertimbangan individu dalam mengambil keputusan akan bergantung pada urutan atau susunan bukti yang disajikan.

\section{Recency, Primacy, dan No Order Effect}

Model Belief Adjustment mengklasifikasikan dua kemungkinan efek urutan pada bukti gabungan yaitu recency effect dan primacy effect. Recency effect terjadi ketika bukti terakhir yang diterimanya lebih dipertimbangkan daripada bukti awal. Primacy effect terjadi ketika bukti pertama lebih dipertimbangkan daripada bukti yang terakhir. Sedangkan no order effect terjadi ketika urutan dari bukti negatif 
pertama yang diikuti bukti negatif kedua memiliki pengaruh yang sama pada revisi keyakinan jika urutan bukti negatif kedua diikuti bukti negatif pertama dan sebaliknya. Berikut gambaran prediksi efek urutan pada Model yang dikembangkan oleh Hogart dan Einhorn (1992).

Tabel 1

Ekspektasi Efek Urutan Berdasarkan Model Belief Adjustment

\begin{tabular}{|c|c|c|c|c|}
\hline & \multicolumn{2}{|l|}{ Simple } & \multicolumn{2}{|l|}{ Complex } \\
\hline & End of sequence & Step by step & End of sequence & Step by step \\
\hline \multicolumn{5}{|c|}{ Mixed information set } \\
\hline Short & Primacy & Recency & Recency & Recency \\
\hline Long & Primacy & Primacy & Primacy & Primacy \\
\hline \multicolumn{5}{|c|}{ Consistant information set } \\
\hline Short & Primacy & No effect & No effect & No effect \\
\hline Long & Primacy & Primacy & Primacy & Primacy \\
\hline
\end{tabular}

Sumber: Hogarth \& Einhorn (1992)

Tabel tersebut menunjukkan seperangkat informasi campuran (urutan informasi ++-- atau --++) dan seperangkat informasi konsisten (urutan ++++ atau ---) yang dapat menunjukkan prediksi efek urutan yang terjadi. Pada penelitian ini menggunakan pola penyajian informasi Step by Step dan End of Sequence, seri informasi panjang dan pendek, dan informasi sederhana. Sehingga berdasarkan prediksi efek yang terjadi yaitu primacy effect pada pola penyajian Step by Step seri informasi panjang, dan pola penyajian End of Sequence pada seri informasi panjang dan pendek. Sedangkan pada pola penyajian Step by Step seri informasi pendek terjadi efek recency. Dari penjelasan tersebut dapat dibuat kerangka pemikiran sebagai berikut:

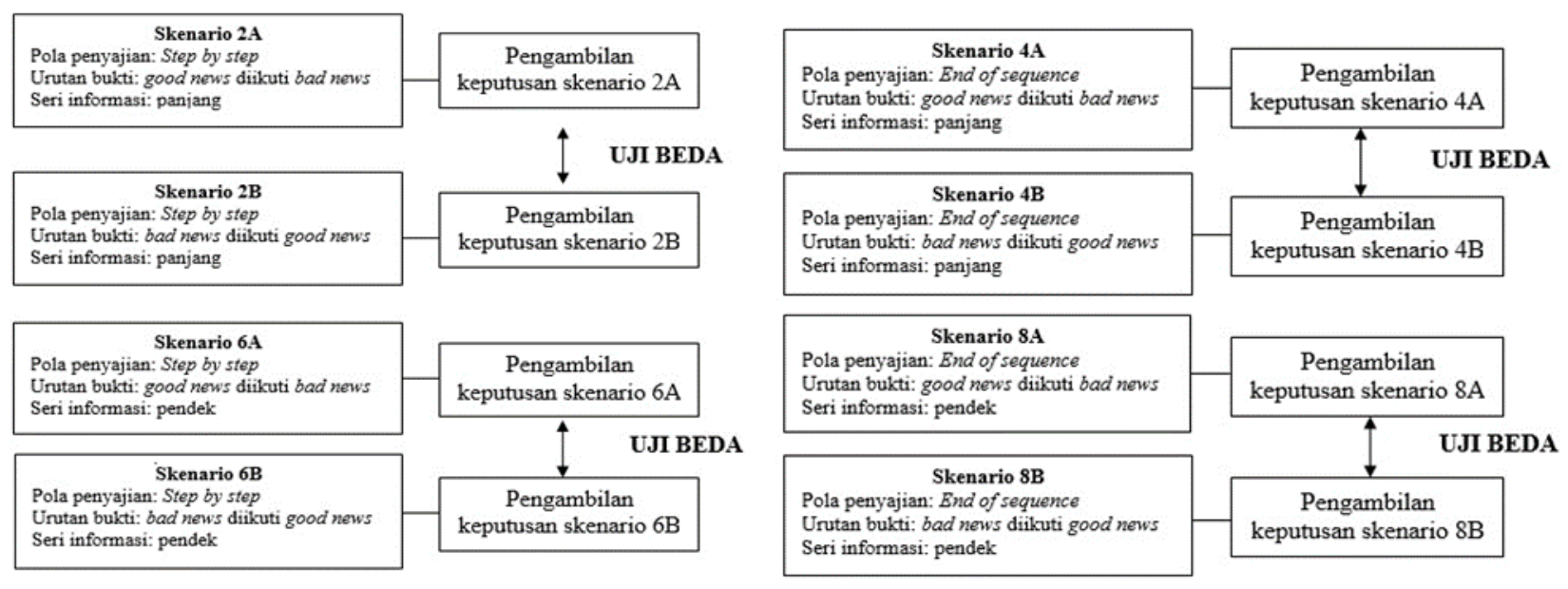

Sumber: Data diolah

\section{Gambar 1 \\ Kerangka Pemikiran Teoritis}

Kerangka pemikiran teoritis menjelaskan bahwa Pada skenario 2A, partisipan akan menerima pola penyajian informasi $S b S$ dengan urutan informasi good news 
diikuti bad news pada seri informasi panjang dan pada skenario 2B partisipan akan menerima pola penyajian $S b S$ dengan urutan informasi bad news diikuti good news pada seri informasi panjang. Berdasarkan Tabel 1 yang telah dijelaskan sebelumnya, pada skenario $2 \mathrm{~A}$ partisipan akan cenderung memberikan proporsi yang lebih tinggi pada informasi yang diterimanya paling awal (primacy), sama halnya pada skenario 2B bahwa partisipan akan cenderung memberikan proporsi yang lebih tinggi pada informasi yang diterimanya paling awal atau disebut dengan primacy effect. Individu menggunakan strategi pengolahan $S b S$, ketika informasi disajikan dalam bentuk SbS. Individu menyesuaikan keyakinannya secara bertahap ketika menerima tiap potongan informasi. Strategi pengolahan $S b S$ memerlukan tuntutan minimal pada memori dan muatan pengolahan informasi, sehingga diperlukan peningkatkan kemampuan untuk menangani tuntutan-tuntutan kognitif dari tugas-tugas tersebut. Almilia et al. (2013) menunjukkan adanya recency effect dalam pengambilan keputusan investasi apabila informasi disajikan secara step by step dan tidak terjadi efek urutan dalam pengambilan keputusan investasi jika informasi disajikan secara simultan end of sequence. Berdasarkan penjelasan latar belakang yang telah dijelaskan sebelumnya, maka dapat dirumuskan hipotesis penelitian sebagai berikut:

H1: Terdapat perbedaan pengambilan keputusan investasi antara partisipan yang menerima informasi good news diikuti bad news dibandingkan partisipan yang menerima informasi bad news diikuti good news pada pola penyajian $S b S$ dan seri informasi panjang.

Pada skenario 6A partisipan akan menerima informasi dengan pola penyajian $S b S$ dengan urutan informasi good news diikuti bad news pada seri informasi pendek dan skenario 6B partisipan akan menerima informasi dengan pola penyajian step by step dengan urutan informasi bad news diikuti good news pada seri informasi pendek. Pada skenario 6A dan 6B partisipan cenderung memberikan proporsi yang lebih tinggi pada informasi yang diterimanya paling akhir (recency) atau disebut juga terjadi recency effect. Kusumawardhani dan Almilia (2015) memberikan bukti bahwa tidak terdapat perbedaan judgment akhir pada pola penyajian step by step berdasarkan urutan informasi panjang sederhana atau tidak terdapat efek urutan. Hasil penelitian Kusumawardhani dan Almilia (2015) berbeda dengan model Belief Adjustment Hogarth dan Einhorn (1992) bahwa dalam seri informasi panjang dan sederhana dengan pola penyajian step by step akan terjadi efek primacy. Berdasarkan penjelasan latar belakang yang telah dijelaskan sebelumnya, maka dapat dirumuskan hipotesis penelitian sebagai berikut:

H2: Terdapat perbedaan pengambilan keputusan investasi antara partisipan yang menerima informasi good news diikuti bad news dibandingkan partisipan yang menerima informasi bad news diikuti good news pada pola penyajian $S b S$ dan seri informasi pendek.

Pada skenario 4A partisipan akan menerima informasi dengan pola penyajian yang berbeda pada skenario sebelumnya, yaitu pola penyajian EoS, urutan informasi 
good news diikuti bad news dan pada seri informasi panjang. Pada skenario 4B partisipan juga akan menerima informasi yang tidak jauh berbeda dengan skenario 4A yaitu, pola penyajian EoS, urutan informasi bad news diikuti good news, dan seri informasi panjang. Berdasarkan Tabel 1 menjelaskan bahwa terjadi primacy effect yaitu, partisipan cenderung memberikan proporsi yang lebih tinggi pada informasi yang diterimanya paling awal. Pengolahan EoS berarti bahwa anchor awal disesuaikan dengan penyajian bukti-bukti secara agregatif. Penyajian dalam bentuk EoS seringkali menghasilkan strategi pengolahan EoS, khususnya bila jumlah item informasi sedikit dan/atau informasi tidak terlalu kompleks. Namun, rangkaianrangkaian item informasi yang relatif kompleks dan/atau panjang yang disampaikan dalam bentuk EoS mungkin tidak tertampung oleh kapasitas kognitif individu. Oleh karena itu, individu secara khusus menggunakan strategi pengolahan SbS saat dihadapkan pada kondisi kognitif seperti itu. Almilia dan Supriyadi (2013) menunjukkan bahwa terdapat perbedaan keputusan investasi antara partisipan yang menerima urutan informasi good news diikuti bad news dibandingkan partisipan yang menerima urutan informasi bad news diikuti good news untuk penyajian informasi end of sequence. Berdasarkan penjelasan latar belakang yang telah dijelaskan sebelumnya, maka dapat dirumuskan hipotesis penelitian sebagai berikut:

H3: Terdapat perbedaan pengambilan keputusan investasi antara partisipan yang menerima informasi good news diikuti bad news dibandingkan partisipan yang menerima informasi bad news diikuti good news pada pola penyajian $E S S$ dan seri informasi panjang.

Pada skenario 8A partisipan akan memperoleh informasi dengan pola penyajian EoS, urutan informasi good news diikuti bad news, dan seri informasi pendek. Sedangkan pada skenario 8B partisipan akan memperoleh informasi dengan pola penyajian $E o S$, urutan informasi bad news diikuti good news, dan seri informasi pendek. Pada skenario tersebut partisipan akan cenderung memberikan proporsi pada informasi yang diterimanya paling awal atau disebut juga primacy effect. Hasil penelitian Pravitasari dan Almilia (2015) menunjukkan hasil bahwa pada pola penyajian end of sequence terjadi efek urutan recency, hal ini tidak mendukung model Belief Adjustment yang dikembangkan oleh Hogarth dan Einhorn (1992) bahwa pada pola penyajian end of sequence akan menimbulkan efek primacy ketika informasi yang diterima masih sederhana. Berdasarkan penjelasan latar belakang yang telah dijelaskan sebelumnya, maka dapat dirumuskan hipotesis penelitian sebagai berikut:

H4: Terdapat perbedaan pengambilan keputusan investasi antara partisipan yang menerima informasi good news diikuti bad news dibandingkan partisipan yang menerima informasi bad news diikuti good news pada pola penyajian $E o S$ dan seri informasi pendek. 


\section{METODA PENELITIAN Rancangan Penelitian}

Penelitian ini tergolong penelitian eksperimen dengan metode eksperimen. Menurut Nahartyo (2012) Metode eksperimen adalah suatu desain eksperimen yang digunakan untuk menginvestigasi suatu fenomena dengan cara merekayasa keadaan atau kondisi dengan melewati prosedur yang telah ditentukan dan kemudian mengamati hasil rekasaya tersebut lalu menginterpretasikannya. Metode eksperimen menjanjikan hasil yang tak diberikan oleh metode lain, yaitu keyakinan yang tinggi atas adanya hubungan sebab akibat antara variabel independen dengan variabel dependen. Metode ini dipilih karena metode eksperimen memiliki kekuatan dalam menjelaskan hubungan sebab akibat antar variabel penelitian.

Penelitian eksperimen ini menggunakan model eksperimen $2 \times 2 \times 2$ mixed design (between subject dan within subject) yang meliputi, pola penyajian informasi (step by step dan end of sequence), urutan penyajian informasi (++-- dan --++), dan seri informasi (seri panjang dan seri pendek).

Kriteria subjek pada sampel yang digunakan pada penelitian ini adalah mahasiswa yang sedang dan/atau telah menempuh mata kuliah Analisa Laporan Keuangan dan/atau mata kuliah Manajemen Investasi Pasar Modal atau Manajemen Investasi Portofolio. Berdasarkan kriteria tersebut maka subjek pada penelitian ini adalah mahasiswa jurusan S1 Akuntansi dan S1 Manajemen. Alasan memilih partisipan mahasiswa jurusan S1 Akuntansi dan S1 Manajemen dikarenakan keduanya memenuhi kriteria peneliti, yaitu keduanya terdapat mata kuliah Manajemen Investasi Pasar Modal atau Manajemen Investasi Portofolio dan Analisa Laporan Keuangan.

\section{Variabel-Variabel Penelitian}

Variabel dependen dalam penelitian ini adalah pengambilan keputusan investasi, sedangkan variabel independen pada penelitian ini adalah pola penyajian informasi (step by step dan end of sequence), urutan bukti (++-- dan --++), dan seri informasi (seri panjang dan seri pendek).

\section{Tugas dan Prosedur Eksperimen}

Penelitian ini berfokus pada pola penyajian informasi ( $S b S$ dan $E o S$ ), urutan bukti (++-- dan --++), dan seri informasi akuntansi (seri panjang dan seri pendek) pada informasi nonakuntansi. Eksperimen yang dilakukan pada penelitian ini menggunakan cara pencil based eksperiment yaitu dilakukan dengan menggunakan kuesioner yang dijawab oleh partisipan secara manual. Partisipan pada penelitian ini akan diminta untuk mengasumsikan peranan investor yang sedang melakukan penilaian kinerja perusahaan berdasarkan informasi nonakuntansi perusahaan.

Penelitian ini menggunakan informasi perusahaan PT. ANT yang dahulu bernama PT. AA merupakan perusahaan dalam bidang basic industry and chemical yang berdiri sejak 25 Maret 1953. Pada 04 Juli 1991, PT. ANT memperoleh 
pernyataan efektif dari Bapepam-LK untuk melakukan Penawaran Umum Perdana Saham (IPO) kepada masyarakat sebanyak 40.000 .000 dengan nilai nominal Rp1.000,00 per saham. Saham-saham tersebut dicatatkan di Bursa Efek Indonesia pada tanggal 08 Juli 1991. Nilai awal saham perusahaan pada tahun 2015 adalah Rp16.200,00 sebagai nilai referensi (berdasarkan informasi pada laporan keuangan perusahaan di BEI). Partisipan diminta memberikan skala untuk masing-masing pengungkapan dengan kelipatan harga -1000 (very bad news) dan +1000 (very good news) pada pola penyajian informasi (step by step dan end of sequence). Partisipan akan diberikan informasi nonakuntansi tentang Good Coorporate Governance dan Coorporate Social Responsibility. Partisipan akan diberikan informasi sejumlah 18 informasi untuk seri panjang dan sejumlah delapan informasi untuk seri pendek.

Adapun informasi good news adalah (1) perusahaan merealisasikan program PKBL (Program Kegiatan Bina Lingkungan) sebagai salah satu program yang ditujukan untuk membantu meningkatkan taraf hidup dan kesejahteraan masyarakat sekitar; (2) perusahaan merealisasikan penyaluran program pinjaman modal kerja; (3) perusahaan dan entitas usaha anak memproduksi produk kemasan sesuai dengan standar maksimum untuk memastikan keselamatan konsumen; (4) perusahaan memberikan beberapa bantuan, antara lain bantuan bencana alam, bantuan peningkatan kesehatan, pengembangan sarana dan prasarana umum, bantuan sarana ibadah dan bantuan pendidikan dalam bentuk beasiswa yang diberikan kepada pelajar; (5) perusahaan membentuk unit kerja Manajemen Risiko yang bertanggung jawab mengkoordinir, mengevaluasi dan memfasilitasi kegiatan pengelolaan risiko di Perseroan; (6) perusahaan menyusun dan menetapkan Pedoman Etika Perusahaan yang mengatur hal-hal yang menjadi tanggung jawab perusahaan, individu Insan Perusahaan, maupun pihak lain yang melakukan aktivitas dengan perusahaan; (7) membangun Waste Heat Recovery Generation, menyediakan tambahan listrik dan memperbaiki kualitas lingkungan; (8) perusahaan dengan transparan menunjukkan tabel penugasan dan kegiatan Dewan Komisaris; (9) perusahaan melaksanakan program penghijauan lingkungan untuk menjaga kelestarian lingkungan sekitar dan kehidupan yang lebih baik.

Informasi negatif atau bad news yang digunakan pada penelitian ini adalah (1) perusahaan belum mengaitkan pelaksanaan kode etik sebagai dasar pengenaan reward dan punishment bagi karyawan; (2) perusahaan harus menghadapi tuntutan karyawan bahwa Direktur Utama harus mengundurkan diri; (3) perusahaan menghadapi tuntutan karyawan terkait dengan pemenuhan kesejahteraan karyawan; (4) perusahaan menghadapi penolakan warga sekitar terkait pembangunan pabrik di beberapa daerah; (5) perusahaan tidak segera menutup (reklamasi) lubang-lubang bekas galian tambang; (6) perusahaan kurang memperhatikan peralatan keselamatan pekerja di lapangan; (7) terdapat sistem penilaian kinerja Dewan Komisaris dan Direksi namun perusahaan belum menetapkan dan melaksanaannya secara konsisten; (8) perusahaan menghadapi tuntutan warga tentang perncemaran limbah yang 
mengganggu warga sekitar; (9) perusahaan belum mempublikasikan kebijakan atau mekanisme tentang pengendalian gratifikasi kepada stakeholder melalui media antara lain website, majalah dan lain lain. Prosedur yang harus dilakukan oleh partisipan ketika melakukan penilaian harga saham yang didasarkan pada pola penyajian informasi ( $S b S$ dan $E o S$ ), dapat digambarkan pada Tabel 2.

Tabel 2

Prosedur Yang Dilakukan Berdasarkan Pola Pengungkapan

\begin{tabular}{|c|c|}
\hline \multicolumn{2}{|c|}{ Pola pengungkapan } \\
\hline Step by Step & End of Sequence \\
\hline $\begin{array}{l}\text { 1. Membaca latar belakang perusahaan. } \\
\text { 2. Diberikan informasi terkait harga awal } \\
\text { saham. } \\
\text { 3. Diberikan informasi pengungkapan laporan } \\
\text { nonakuntansi terkait dengan Good } \\
\text { Coorporate Governance dan Coorporate } \\
\text { Social Responsibility. Pada skenario 2A dan } \\
\text { skenario 2B diberikan informasi sebanyak } 18 \\
\text { item dan pada skenario 6A dan skenario 6B } \\
\text { diberikan informasi sebanyak delapan item. } \\
\text { 4. Melakukan penilaian nilai saham perusahaan } \\
\text { sebanyak 18 kali (untuk skenario 2A dan } \\
\text { skenario 2B) dan sebanyak delapan kali } \\
\text { (untuk skenario 6A dan skenario 6B) } \\
\text { 5. Partisipan diminta merespon pertanyaan } \\
\text { manipulation check dan pertanyaan } \\
\text { pengetahuan dasar akuntansi untuk } \\
\text { mengukur kemampuan dasar partisipan } \\
\text { dibidang Analisa Laporan Keuangan dan } \\
\text { Manajemen Investasi Pasar Modal atau } \\
\text { Manajemen Investasi Portofolio. }\end{array}$ & $\begin{array}{l}\text { 1. Membaca latar belakang perusahaan. } \\
\text { 2. Diberikan informasi terkait harga awal } \\
\text { saham } \\
\text { 3. Diberikan informasi pengungkapan laporan } \\
\text { nonakuntansi terkait dengan Good } \\
\text { Coorporate Governance dan Coorporate } \\
\text { Social Responsibility. Pada skenario 4A dan } \\
\text { skenario 4B diberikan informasi sebanyak } 18 \\
\text { item dan pada skenario 8A dan skenario 8B } \\
\text { diberikan informasi sebanyak delapan item. } \\
\text { 4. Melakukan penilaian nilai saham perusahaan } \\
\text { sebanyak satu kali pada skenario 4A, 4B, } \\
\text { 8A, dan 8B dB pertanyaan } \\
\text { 5. Partisipan diminta merespon pertanyaan } \\
\text { manipulation check dan untuk } \\
\text { pengetahuan dasar akuntansi un untisipan } \\
\text { mengukur kemampuan dasar partisian } \\
\text { dibidang Analisa Laporan Keuangan dan } \\
\text { Manajemen Investasi Pasar Modal atau } \\
\text { Manajemen Investasi Portofolio. } \\
\text { 6. Sesi Debriefing. }\end{array}$ \\
\hline
\end{tabular}

6. Sesi Debriefing.

Sumber: Data diolah

\section{Teknik Analisis Data}

Teknik analisis data yang digunakan untuk menguji hipotesis pada penelitian ini adalah Uji Normalitas dan Uji beda Mann-Whitney. Uji Normalitas bertujuan menguji apakah variabel terikat dan variabel bebas berdistribusi normal atau tidak. Data dapat dikatakan berdistribusi normal apabila nilai signifikan $>\alpha 0,05$. Apabila data berdistribusi normal maka dilakukan uji parametric sample t-test dan apabila data tidak berdistribusi normal maka dilakukan uji nonparametric mann-whitney.

Selanjutnya uji beda t-test digunakan untuk menentukan perbedaan sampel. Ketentuan yang digunakan pada uji beda t-test adalah apabila tingkat signifikan $<0,05$ maka $\mathrm{H}_{0}$ ditolak, yang berarti terdapat perbedaan, namun apabila tingkat signifikasi $\geq 0,05$ maka $\mathrm{H}_{0}$ diterima yang berarti tidak terdapat perbedaan. Sedangkan uji Mann-Whitney digunakan untuk mengetahui perbedaan median dua kelompok bebas apabila skala dan variabel terikatnya adalah ordinal atau interval/ratio tetapi tidak berdistribusi normal. 


\section{ANALISIS DAN PEMBAHASAN}

\section{Data Demografi dan Cek Manipulasi}

Kriteria subjek pada penelitian ini yaitu mahasiswa S1 Akuntansi dan S1 Manajemen yang telah menempuh dan/atau sedang menempuh mata kuliah Analisa Laporan Keuangan dan/atau Manajemen Investasi Pasar Modal atau Manajemen Investasi Portofolio yang memiliki Indeks Prestasi Kumulatif (IPK) $\geq 3,25$. terdapat 120 Mahasiswa yang telah bersedia menjadi partisipan pada penelitian ini, yaitu 97 mahasiswa Akuntansi dan 23 mahasiswa Manajemen. Akan tetapi terdapat beberapa partisipan yang mengundurkan diri dikarenakan terdapat keperluan lain yang tidak dapat ditinggalkan yaitu sebanyak tujuh mahasiswa, dua diantaranya adalah jurusan S1 Akuntansi dan 5 diantara jurusan S1 Manajemen, sehingga digantikan oleh partisipan lain yang bersedia. Pada pelaksanaan eksperimen terdapat 22 partisipan yang datang terlambat sehingga tidak dapat mengikuti penugasan eksperimen. Banyaknya jumlah partisipan yang terlambat dikarenakan pada saat pelaksanaan eksperimen cuaca dilokasi penugasan tidak mendukung, oleh karena itu banyak partisipan yang tidak dapat mengikuti penugasan dikarenakan terlambat hadir. Pada penelitian ini terdapat lima data partisipan yang tidak dapat digunakan dikarenakan tidak lolos cek pengetahuan umum akuntansi, sehingga data partisipan yang dapat diolah sebanyak 91 mahasiswa 74 diantaranya adalah mahasiswa S1 Akuntansi dan 17 diantaranya adalah mahasiswa S1 Manajemen.

Partisipan dinyatakan lolos dalam cek pengetahuan umum akuntansi apabila memiliki jawaban benar yang sesuai dengan kriteria yang ditentukan oleh peneliti. Kriteria cek pengetahuan umum akuntansi terdapat dua alternatif, yaitu pertama cek pengetahuan umum akuntansi dianggap lolos apabila partisipan telah menjawab minimal benar dua dari lima pertanyaan. Kedua, cek pengetahuan umum akuntansi dianggap lolos apabila partisipan telah menjawab minimal benar satu dari lima pertanyaan. Sedangkan cek manipulasi hanya terdapat satu alternatif yaitu cek manipulasi dianggap lolos apabila partisipan telah menjawab minimal benar dua dari tiga pertanyaan. Cek pengetahuan umum akuntansi pada penelitian ini terdapat beberapa penggunaan alternatif. Pada skenario $6 \mathrm{~A}$ dan skenario $4 \mathrm{~B}$ menggunakan alternatif satu sedangkan skenario 2A, 2B, 4A, 6B, 8A, dan 8B menggunakan alternatif 2. Penggunaan alternatif 1 digunakan apabila jumlah partisipan pada skenario telah melebihi 10 orang, sedangkan alternatif 2 digunakan apabila jumlah partisipan pada skenario tersebut telah kurang dari 10 orang.

\section{Pengujian Pengaruh Pola Penyajian Step by Step dan Seri Informasi Panjang}

Tabel 3 menunjukkan bahwa rata-rata judgment akhir pada urutan informasi ++-- lebih rendah yaitu 13.866,67 dibandingkan dengan judgment akhir pada urutan informasi --++ yaitu sebesar 19.533,33. Kualitas data selanjutnya diuji menggunakan uji normalitas. Alat uji yang digunakan yaitu Kolmogorov Smirnov. Tujuan dari pengujian ini untuk mengetahui distribusi data. Data dapat dikatakan terdistribusi 
normal apabila nilai signifikansi lebih besar dari 0,05. Hasil dari uji Kolmogorov Smirnov dapat dilihat pada Tabel 4.

Berdasarkan tabel hasil uji beda diperoleh informasi bahwa nilai probabilitas dari urutan bukti informasi adalah 0.000 . Hasil tersebut $\leq 0.05$ yang artinya $\mathrm{H} 1$ diterima dan $\mathrm{H} 0$ ditolak maka hipotesis satu dinyatakan terdapat perbedaan. Pada Tabel 5 diketahui bahwa rata-rata judgment akhir kelompok subjek yang menerima urutan informasi ++-- sebesar 13.866,67 lebih rendah dibandingkan dengan kelompok subjek yang menerima urutan informasi --++ sebesar 19.533,33.

Tabel 3

Rata-Rata Judgment Akhir Pola Penyajian Step By Step Seri Informasi Panjang

\begin{tabular}{|c|c|c|c|c|c|c|c|c|c|}
\hline \multirow{2}{*}{$\begin{array}{c}\text { Urutan } \\
\text { Bukti }\end{array}$} & \multicolumn{9}{|c|}{ Judgment } \\
\hline & Ke-1 & Ke-2 & Ke-3 & Ke-4 & Ke-5 & Ke-6 & Ke-7 & Ke-8 & Ke-9 \\
\hline++-- & 15533,33 & 16533,33 & 16616,67 & 17450 & 16783,33 & 15866,67 & 17366,67 & 17866,67 & 17783,33 \\
\hline--++ & 14616,67 & 13950 & 14866,67 & 13366,67 & 12616,67 & 13366,67 & 14033,33 & 13283,33 & 13700 \\
\hline \multirow{2}{*}{$\begin{array}{l}\text { Urutan } \\
\text { Bukti }\end{array}$} & \multicolumn{9}{|c|}{ Judgment } \\
\hline & Ke-10 & Ke-11 & Ke-12 & $\mathrm{Ke}-13$ & Ke-14 & Ke-15 & Ke-16 & Кe-17 & Ke-18 \\
\hline ++-- & 14366,67 & 14533,33 & 15283,33 & 14033,33 & 13783,33 & 13950 & 14366,67 & 12950 & 13866,67 \\
\hline--++ & 16450 & 16450 & 17616,67 & 18033,33 & 18450 & 18783,33 & 19033,33 & 18450 & 19533,33 \\
\hline
\end{tabular}

Tabel 4

Hasil Uji Normalitas

\begin{tabular}{ccccc}
\hline \multirow{2}{*}{ Variabel } & \multirow{2}{*}{ Responden } & \multicolumn{2}{c}{ Nilai } & \multirow{2}{*}{ Keterangan } \\
\cline { 3 - 4 } & Mahasiswa & 0,158 & 0,125 & Normal \\
\hline Harga Saham & & & &
\end{tabular}

Tabel 5

Hasil Uji Beda Independent Sample T-Test

\begin{tabular}{ccccc}
\hline $\begin{array}{c}\text { Pola } \\
\text { Penyajian }\end{array}$ & $\begin{array}{c}\text { Urutan } \\
\text { Bukti }\end{array}$ & $\begin{array}{c}\text { Seri } \\
\text { Informasi }\end{array}$ & Mean & Sig. 2-tailed \\
\hline$S B S$ & ++-- & Panjang & $13.866,67$ & 0,000 \\
$S B S$ & --++ & Panjang & $19.533,33$ & \\
\hline Sumber: Data diolah & & &
\end{tabular}

\section{Pengujian Pengaruh Pola Penyajian Step by Step dan Seri Informasi Pendek}

Tabel 6 menunjukkan bahwa rata-rata judgment akhir kelompok subjek yang menerima urutan informasi ++-- lebih rendah yaitu 15.472,73 dibandingkan dengan judgment akhir kelompok subjek yang menerima urutan informasi --++ yaitu sebesar $18.018,18$. Pengujian berikutnya yaitu menguji kualitas data menggunakan uji normalitas. Alat uji yang digunakan yaitu Kolmogorov Smirnov. Tujuan dari pengujian ini untuk mengetahui distribusi data. Data dapat dikatakan terdistribusi normal apabila nilai signifikansi lebih besar dari 0,05. 
Berdasarkan hasil Tabel 7 diketahui bahwa nilai signifikansi dari Urutan bukti informasi terhadap judgment akhir mahasiswa terdistribusi normal sebesar $0,125 \geq 0,05$ maka dapat disimpulkan data berdistribusi normal. Apabila data berdistribusi normal maka tahapan selanjutnya yaitu uji beda Independent Sample ttest.

Tabel 8 menunjukkan hasil pengujian hipotesis dua penelitian ini yaitu pola penyajian Step by Step dan seri informasi panjang. Hipotesis dua pada penelitian ini yaitu terdapat perbedaan keputusan investasi antara partisipan yang menerima informasi good news diikuti bad news dibandingkan partisipan yang menerima informasi bad news diikuti good news pada pola penyajian Step by Step dan seri informasi pendek. Pengujian dengan menggunakan uji beda Independent Sample ttest menentukan apakah terdapat perbedaan signifikan atau tidak terdapat perbedaan signifikan.

Berdasarkan tabel hasil uji beda diperoleh informasi bahwa nilai probabilitas dari urutan bukti informasi adalah 0.028 . Hasil tersebut $\leq 0.05$ yang artinya $\mathrm{H} 2$ diterima dan $\mathrm{H}_{0}$ ditolak maka hipotesis kedua pada penelitian ini dinyatakan terdapat perbedaan. Pada Tabel 8 diketahui bahwa rata-rata judgment akhir subjek yang menerima urutan informasi ++-- yang terlihat pada Tabel 8 sebesar 15.472,73 lebih rendah dibandingkan dengan subjek yang menerima urutan informasi --++ sebesar $18.018,18$.

Tabel 6

Rata-Rata Judgment Akhir Pola Penyajian Step By Step Seri Informasi Pendek

\begin{tabular}{ccccccccc}
\hline \multirow{2}{*}{$\begin{array}{c}\text { Urutan } \\
\text { Bukti }\end{array}$} & Ke-1 & Ke-2 & Ke-3 & Ke-4 & Ke-5 & Ke-6 & Ke-7 & Ke-8 \\
\cline { 2 - 9 } & 15109,09 & 15200 & 16018,18 & 16654,55 & 14018,18 & 13563,64 & 14018,18 & 15472,73 \\
++-- & 15472,73 & 14563,64 & 14472,73 & 15381,82 & 17563,64 & 17563,64 & 18200 & 18018,18 \\
++-- & 15470
\end{tabular}

Tabel 7

Hasil Uji Normalitas

\begin{tabular}{ccccc}
\hline \multirow{2}{*}{ Variabel } & \multirow{2}{*}{ Responden } & \multicolumn{2}{c}{ Nilai } & \multirow{2}{*}{ Keterangan } \\
\cline { 3 - 4 } & Mahasiswa & 0,117 & 0,200 & Normal \\
\hline Harga Saham & & & &
\end{tabular}

Tabel 8

Hasil Uji Beda Independent Sample T-Test

\begin{tabular}{ccccc}
\hline $\begin{array}{c}\text { Pola } \\
\text { Penyajian }\end{array}$ & $\begin{array}{c}\text { Urutan } \\
\text { Bukti }\end{array}$ & $\begin{array}{c}\text { Seri } \\
\text { Informasi }\end{array}$ & Mean & Sig. 2-tailed \\
\hline$S b S$ & ++-- & Pendek & $15.472,73$ & 0,028 \\
$S b S$ & --++ & Pendek & $18.018,18$ & \\
\hline
\end{tabular}

Sumber: Data diolah 


\section{Pengujian Pengaruh Pola Penyajian End of Sequence dan Seri Informasi Panjang}

Berdasarkan Tabel 9 terdapat hasil uji normalitas yang diuji menggunakan alat uji Kolmogorv Smirnov, diketahui bahwa signifikansi sebesar 0,200 $\geq 0,05$ yang dapat disimpulkan bahwa data terdistribusi normal. Tahapan selanjutnya yaitu melakukan pengujian uji beda Independent Sample t-test. Uji beda Independent Sample t-test bertujuan untuk melihat apakah terdapat perbedaan signifikan pada kelompok subjek yang menerima urutan informasi ++-- dibandingkan dengan kelompok subjek yang menerima urutan informasi --++.

Tabel 10 menunjukkan hasil pengujian hipotesis tiga penelitian ini yaitu pola penyajian end of sequence dan seri informasi panjang. Hipotesis ketiga pada penelitian ini yaitu terdapat perbedaan keputusan investasi antara partisipan yang menerima informasi good news diikuti bad news dibandingkan partisipan yang menerima informasi bad news diikuti good news pada pola penyajian end of sequence dan seri informasi panjang. Pengujian dengan menggunakan uji beda Independent Sample t-test menentukan apakah terdapat perbedaan signifikan atau tidak terdapat perbedaan signifikan.

Berdasarkan tabel hasil uji beda diperoleh informasi bahwa nilai probabilitas dari urutan bukti informasi adalah 0.046 . Hasil tersebut $\leq 0.05$ yang artinya H3 diterima dan $\mathrm{H} 0$ ditolak maka hipotesis ketiga pada penelitian ini dinyatakan terdapat perbedaan. Pada Tabel 10 diketahui bahwa rata-rata judgment akhir subjek yang menerima urutan informasi ++-- yang terlihat pada Tabel 10 sebesar 15.927,27 lebih rendah dibandingkan dengan subjek yang menerima urutan informasi --++ sebesar 17700. Hasil dari pengujian diatas disimpulkan bahwa terdapat perbedaan judgment akhir partisipan skenario 4A dan 4B terhadap pengambilan keputusan investasi.

Tabel 9

Hasil Uji Normalitas

\begin{tabular}{|c|c|c|c|c|}
\hline \multirow{2}{*}{ Variabel } & \multirow{2}{*}{ Responden } & \multicolumn{2}{|c|}{ Nilai } & \multirow{2}{*}{ Keterangan } \\
\hline & & $\mathbf{Z}$ & Sig & \\
\hline Harga Saham & Mahasiswa & 0,154 & 0,200 & Normal \\
\hline
\end{tabular}

Sumber: Data diolah

Tabel 10

Hasil Uji Beda Independent Sample T-Test

\begin{tabular}{ccccc}
\hline $\begin{array}{c}\text { Pola } \\
\text { Penyajian }\end{array}$ & $\begin{array}{c}\text { Urutan } \\
\text { Bukti }\end{array}$ & $\begin{array}{c}\text { Seri } \\
\text { Informasi }\end{array}$ & Mean & Sig. 2-tailed \\
\hline$E o S$ & ++-- & Panjang & $15.927,27$ & 0.046 \\
$E o S$ & --++ & Panjang & 17700 & 0.000 \\
\hline
\end{tabular}

Sumber: Data diolah

\section{Pengujian Pengaruh Pola Penyajian End of Sequence dan Seri Informasi Pendek}

Tabel 11 terdapat hasil uji normalitas yang diuji menggunakan alat uji Kolmogorv Smirnov, diketahui bahwa signifikansi sebesar $0,103 \geq 0,05$ dapat disimpulkan bahwa data telah terdistribusi secara normal. Tahapan selanjutnya 
adalah melakukan pengujian uji beda Independent Sample t-test. Uji beda Independent Sample t-test bertujuan untuk melihat apakah terdapat perbedaan signifikan pada kelompok subjek yang menerima urutan informasi ++-dibandingkan dengan kelompok subjek yang menerima urutan informasi --++.

Tabel 12 menunjukkan hasil pengujian hipotesis keempat penelitian ini yaitu pola penyajian end of sequence dan seri informasi pendek. Hipotesis keempat pada penelitian ini yaitu terdapat perbedaan keputusan investasi antara partisipan yang menerima informasi good news diikuti bad news dibandingkan partisipan yang menerima informasi bad news diikuti good news pada pola penyajian end of sequence dan seri informasi pendek. Pengujian dengan menggunakan uji beda Independent Sample t-test untuk menentukan apakah terdapat perbedaan siginifikan atau tidak terdapat perbedaan signifikan. Berdasarkan tabel hasil uji beda diatas diperoleh informasi bahwa nilai probabilitas dari urutan bukti informasi adalah 0.136 $\geq 0.05$ yang artinya $\mathrm{H} 4$ ditolak dan $\mathrm{H} 0$ diterima maka hipotesis keempat pada penelitian ini dinyatakan tidak terdapat perbedaan. Pada Tabel 12 diketahui bahwa rata-rata judgment akhir subjek yang menerima urutan informasi ++-- yang terlihat pada Tabel 12 sebesar 16.200 lebih rendah dibandingkan dengan subjek yang menerima urutan informasi --++ sebesar 17450. Hasil dari pengujian diatas dapat disimpulkan bahwa tidak terdapat perbedaan judgment akhir partisipan skenario 8A dan 8B terhadap pengambilan keputusan investasi.

Tabel 11

Hasil Uji Normalitas

\begin{tabular}{ccccc}
\hline \multirow{2}{*}{ Variabel } & \multirow{2}{*}{ Responden } & \multicolumn{2}{c}{ Nilai } & \multirow{2}{*}{ Keterangan } \\
\cline { 3 - 4 } & & $\mathbf{Z}$ & Sig & \multirow{2}{*}{ Nahasiswa } \\
Harga Saham & 0,162 & 0,103 & Normal \\
\hline Sumber: Data diolah & & & &
\end{tabular}

Tabel 12

Hasil Uji Beda Independent Sample T-Test

\begin{tabular}{ccccc}
\hline $\begin{array}{c}\text { Pola } \\
\text { Penyajian }\end{array}$ & $\begin{array}{c}\text { Urutan } \\
\text { Bukti }\end{array}$ & $\begin{array}{c}\text { Seri } \\
\text { Informasi }\end{array}$ & Mean & Sig. 2-tailed \\
\hline$E o S$ & ++-- & Pendek & 16200 & 0,136 \\
$E o S$ & --++ & Pendek & 17450 & \\
\hline Sumber: Data & & &
\end{tabular}

Sumber: Data diolah

\section{Pembahasan Pengaruh Pola Penyajian Step by Step dan Seri Informasi Panjang}

Hipotesis pada pembahasan ini yaitu terdapat perbedaan keputusan investasi antara partisipan yang memperoleh urutan informasi good news diikuti bad news dibandingkan partisipan yang menerima informasi bad news diikuti good news pada pola penyajian step by step dan seri informasi panjang. Ringkasan hasil pengujian hipotesis disajikan pada Tabel 13. Hasil tersebut mendukung penelitian yang dilakukan oleh Pinsker (2011), Almilia et al. (2013), serta Ananda dan Utami (2014), dan tidak mendukung hasil penelitian dari Hogarth dan Einhorn (1992). Pada penelitian Pinsker (2011) dijelaskan bahwa efek urutan terjadi semakin besar yakni 
Recency Effect pada pola penyajian sekuensial atau informasi disajikan secara berurutan, sedangkan Ekspektasi Model Belief Adjustment yang dikemukakan oleh Hogarth dan Einhorn (1992) menyebutkan bahwa Primacy Effect terjadi apabila informasi disajikan secara berurutan dan seri informasi panjang berdasarkan informasi sederhana. Hasil tersebut didukung dengan pola fishtail yang disajikan pada Gambar 2.

Gambar 2 menjelaskan bahwa kelompok subjek skenario 2A dengan urutan informasi good news diikuti bad news memberikan judgment lebih rendah dibandingkan dengan kelompok subjek skenario 2B. Berdasarkan pola fishtail tersebut dapat diketahui bahwa terjadi recency effect, Terbukti bahwa rata-rata judgment akhir kelompok subjek yang berada pada skenario 2A sebesar 13.866,67 lebih rendah dibandingkan rata-rata judgment akhir kelompok subjek yang berada pada skenario 2B sebesar 19.533,33. Penyebab terjadinya recency effect adalah penyajian informasi secara berurutan memberikan banyak kesempatan untuk melakukan penyesuaian, dan investor sering melakukan penyesuaian yang berlebihan (over adjust) ke arah informasi tersebut. Penyesuaian yang berlebihan ini menyebabkan recency effect. Kesimpulan pada pembahasan ini yaitu hipotesis yang telah dirumuskan terdukung yakni terdapat perbedaan keputusan investasi antara partisipan yang memperoleh urutan informasi good news diikuti bad news dibandingkan partisipan yang menerima informasi bad news diikuti good news pada pola penyajian step by step dan seri informasi panjang. Hasil dari pembahasan ini menghasilkan recency effect. Hasil tersebut konsisten dengan penelitian Pinsker (2011) dan Ananda dan Utami (2014). Hasil ini tidak konsisten dengan hasil penelitian Hogarth dan Einhorn (1992).

Tabel 13

Ringkasan Hasil Pengujian Hipotesis 1

\begin{tabular}{ccc}
\hline Pola Penyajian Informasi & Seri Informasi & Effect yang terjadi \\
\hline Step by step & Panjang & Recency Effect \\
\hline Sumber: Data diolah & &
\end{tabular}

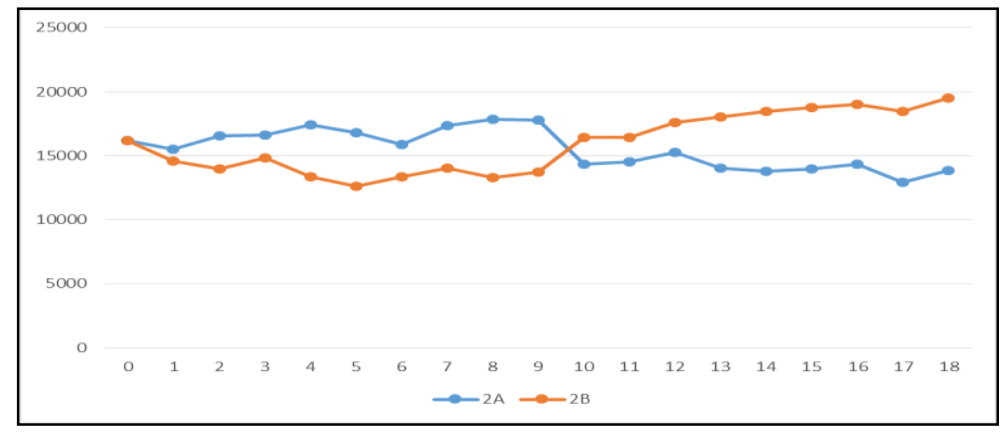

Sumber: Data diolah

Gambar 2

Pola Fishtail Revisi Keyakinan yang diambil oleh Investor pada Pola Penyajian Step by Step dan Seri Informasi Panjang 


\section{Pembahasan Pengaruh Pola Penyajian Step by Step dan Seri Informasi Pendek}

Hipotesis pembahasan ini yaitu terdapat perbedaan keputusan investasi antara partisipan yang memperoleh urutan informasi good news diikuti bad news dibandingkan partisipan yang menerima informasi bad news diikuti good news pada pola penyajian $S b S$ dan seri informasi pendek. Ringkasan hasil pengujian hipotesis pada pembahasan ini disajikan pada Tabel 14.

Tabel 14

Ringkasan Hasil Pengujian Hipotesis 2

\begin{tabular}{ccc}
\hline Pola Penyajian Informasi & Seri Informasi & Effect yang terjadi \\
\hline Step by step & Pendek & Recency Effect \\
\hline Sumber: Data diolah & &
\end{tabular}

Hasil pengujian hipotesis pada Tabel 14 konsisten dengan penelitian yang dilakukan oleh Almilia et al. (2013), Almilia dan Supriyadi (2013), dan konsisten pada penelitian Hogarth dan Einhorn (1992). Ekspektasi Model Belief Adjustment yang dikemukakan oleh Hogarth dan Einhorn (1992) menyebutkan bahwa Recency Effect akan terjadi apabila informasi disajikan secara berurutan dan seri informasi pendek berdasarkan informasi sederhana. Hasil tersebut didukung dengan pola fishtail yang disajikan pada Gambar 3.

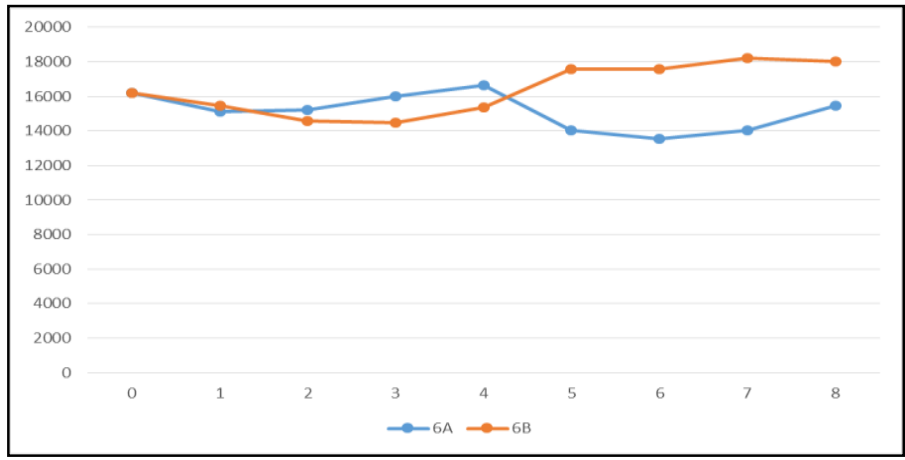

Sumber: Data diolah

Gambar 3

Pola Fishtail Revisi Keyakinan Yang Diambil Oleh Investor Pada Pola Penyajian Step By Step Dan Seri Informasi Pendek

Gambar 3 memberikan informasi bahwa kelompok subjek skenario 6A dengan urutan informasi good news diikuti bad news memberikan judgment lebih rendah dibandingkan dengan kelompok subjek skenario 6B. Berdasarkan pola fishtail tersebut dapat diketahui bahwa terjadi recency effect, Terbukti bahwa rata-rata judgment akhir kelompok subjek yang berada pada skenario 6A sebesar 15.472,73 lebih rendah dibandingkan rata-rata judgment akhir kelompok subjek yang berada pada skenario 6B sebesar 18.018,18. Penyebab terjadinya recency effect ini dikarenakan penyajian informasi secara berurutan atau sekuensial memberikan 
kesempatan yang cukup banyak untuk melakukan penyesuaian, dan investor sering melakukan penyesuaian yang berlebihan (over adjust) ke arah informasi tersebut. Penyesuaian yang berlebihan ini menyebabkan recency effect. Kesimpulan pada pembahasan ini yaitu hipotesis yang telah dirumuskan terdukung yakni terdapat perbedaan keputusan investasi antara partisipan yang memperoleh urutan informasi good news diikuti bad news dibandingkan partisipan yang menerima informasi bad news diikuti good news pada pola penyajian $S b S$ dan seri informasi panjang. Hasil dari pembahasan ini menghasilkan recency effect. Hasil tersebut konsisten dengan penelitian Almilia et al. (2013), Almilia dan Supriyadi (2013), dan konsisten pada penelitian Hogarth dan Einhorn (1992).

\section{Pembahasan Pengaruh Pola Penyajian End of Sequence dan Seri Informasi Panjang}

Hipotesis pada penelitian ini menguji apakah terdapat perbedaan pengambilan keputusan investasi antara partisipan yang menerima informasi good news diikuti bad news dibandingkan partisipan yang menerima informasi bad news diikuti good news pada pola penyajian EoS dan seri informasi panjang. Tabel 15 menjelaskan hasil pengujian hipotesis pada pembahasan ini:

Tabel 15

Ringkasan Hasil Pengujian Hipotesis 3

\begin{tabular}{ccc}
\hline Pola Penyajian Informasi & Seri Informasi & Effect yang terjadi \\
\hline End of sequence & Panjang & Recency Effect \\
\hline Sumber: Data diolah & &
\end{tabular}

Hasil pengujian hipotesis pada Tabel 15 konsisten dengan penelitian yang dilakukan oleh Pinsker (2011), dan tidak konsisten dengan penelitian Hogarth dan Einhorn (1992). Ekspektasi Model Belief Adjustment yang dikemukakan oleh Hogarth dan Einhorn (1992) menyebutkan bahwa Primacy Effect terjadi apabila informasi disajikan secara berurutan dan seri informasi panjang berdasarkan informasi sederhana. Berdasarkan rata-rata judgment akhir kelompok subjek yang menerima urutan informasi good news diikuti bad news pada skenario 4A memberikan judgment lebih rendah dibandingkan dengan kelompok subjek yang menerima urutan informasi bad news diikuti good news pada skenario 4B. Berdasarkan Tabel 15 diketahui bahwa terjadi recency effect, Terbukti bahwa ratarata judgment akhir kelompok subjek yang berada pada skenario 4A sebesar 15.927,27 lebih rendah dibandingkan rata-rata judgment akhir kelompok subjek yang berada pada skenario 4B sebesar 17.700. Kesimpulan pada pembahasan ini yaitu hipotesis yang telah dirumuskan terdukung yakni terdapat perbedaan keputusan investasi antara partisipan yang memperoleh urutan informasi good news diikuti bad news dibandingkan partisipan yang menerima informasi bad news diikuti good news pada pola penyajian $E o S$ dan seri informasi panjang. Hasil dari pembahasan ini menghasilkan recency effect. Hasil tersebut konsisten dengan penelitian Almilia dan 
Supriyadi (2013) yang menyatakan recency effect terjadi pada pola penyajian EoS, dan tidak konsisten dengan penelitian Hogarth dan Einhorn (1992) yang menyatakan bahwa primacy effect terjadi pada pola penyajian $E o S$ dan seri informasi panjang.

\section{Pembahasan Pengaruh Pola Penyajian End of Sequence dan Seri Informasi Pendek}

Hipotesis pada pembahasan ini menguji apakah terdapat perbedaan pengambilan keputusan investasi antara partisipan yang menerima informasi good news diikuti bad news dibandingkan partisipan yang menerima informasi bad news diikuti good news pada pola penyajian EoS dan seri informasi pendek. Tabel 16 memberikan informasi hasil pengujian hipotesis pada pembahasan ini:

Tabel 16

Ringkasan Hasil Pengujian Hipotesis 4

\begin{tabular}{ccc}
\hline Pola Penyajian Informasi & Seri Informasi & Effect yang terjadi \\
\hline End of Sequence & Pendek & No order Effect \\
\hline Sumber: Data diolah & &
\end{tabular}

Hasil pengujian hipotesis pada Tabel 16 dinyatakan No Order Effect. Hasil tersebut tidak konsisten dengan teori yang dikemukakan oleh Hogarth dan Einhorn (1992). Ekspektasi Model Belief Adjustment yang dikemukakan oleh Hogarth dan Einhorn (1992) menyebutkan bahwa Primacy Effect terjadi apabila informasi disajikan secara simultan dan seri informasi pendek berdasarkan informasi sederhana. Hasil dari penelitian ini konsisten dengan hasil penelitian dari Trotman dan Wright (1996), Ashton dan Kennedy (2002), dan Pinsker (2007) bahwa pada pola penyajian $E o S$ tidak terjadi efek urutan.

Kesimpulan pada pembahasan ini yaitu hipotesis yang telah dirumuskan ditolak yakni tidak terdapat perbedaan keputusan investasi antara partisipan yang memperoleh urutan informasi good news diikuti bad news dibandingkan partisipan yang menerima informasi bad news diikuti good news pada pola penyajian EoS dan seri informasi panjang. Hasil dari pembahasan ini menghasilkan no order effect. Hasil tersebut konsisten dengan penelitian Trotman dan Wright (1996), Ashton dan Kennedy (2002), dan Pinsker (2007), tidak konsisten dengan penelitian dari Hogarth dan Einhorn (1992) yang menyatakan bahwa primacy effect terjadi pada pola penyajian EoS dan seri informasi pendek. Hasil dari pembahasan hipotesis pada penelitian ini dinyatakan bahwa tiga hipotesis diterima dan satu hipotesis ditolak yakni $\mathrm{H} 1, \mathrm{H} 2$, dan $\mathrm{H} 3$ diterima tetapi $\mathrm{H} 4$ ditolak.

\section{SIMPULAN, KETERBATASAN DAN SARAN}

\section{Kesimpulan}

Kesimpulan yang dapat ditarik pada penelitian ini yaitu $\mathrm{H} 1$ pada penelitian ini dinyatakan diterima dengan nilai probabilitas $0.000 \leq 0.005$ dan menimbulkan 
Recency Effect, dibuktikan dengan rata-rata judgment akhir partisipan yang menerima skenario 2A dengan urutan informasi ++-- sebesar 13.866,67 lebih rendah dibandingkan partisipan yang menerima skenario 2B dengan urutan informasi --++ sebesar 19.533,33. Hasil ini konsisten dengan penelitian Almilia et al. (2013), Almilia dan Supriyadi (2013) serta Ananda dan Utami (2014) yang menyatakan Recency Effect terjadi pada pola penyajian $S b S$ dan seri informasi panjang. Hasil hipotesis ini tidak konsisten dengan temuan dari Hogarth dan Einhorn (1992) yang menyatakan bahwa terjadi Primacy Effect pada pola penyajian $S b S$ dan seri informasi panjang.

$\mathrm{H} 2$ pada penelitian ini dapat diterima dengan nilai probabilitas sebesar 0.028 $\leq 0.005$ dan menimbulkan Recency Effect, dibuktikan dengan rata-rata Judgment akhir kelompok subjek yang menerima skenario 6A dengan urutan informasi ++-sebesar 15.472,73 lebih rendah dibandingkan partisipan yang menerima skenario 6B dengan urutan informasi --++ sebesar 18.018,18. Hasil tersebut selaras dengan temuan dari Hogarth dan Einhorn (1992) dan Almilia et al., (2013) yang menyatakan terjadi efek Recency Effect pada pola penyajian $S b S$ dan seri informasi pendek.

Hipotesis berikutnya yaitu, H3 pada penelitian ini dinyatakan diterima dengan nilai probabilitas $0.046 \leq 0.005$ dan menimbulkan Recency Effect, dibuktikan dengan rata-rata Judgment akhir partisipan yang menerima skenario 4A dengan urutan informasi ++-- sebesar 15.927,27 lebih rendah dibandingkan partisipan yang menerima skenario 4B dengan urutan informasi --++ sebesar 17.700. Hasil ini selaras dengan penelitian Almilia et al., (2013) dan Pinsker (2011) bahwa terjadi Recency Effect pada pola penyajian EoS dan seri informasi panjang. Hasil ini tidak mendukung hasil temuan dari Hogarth dan Einhorn (1992) yang menyatakan bahwa Primacy Effect terjadi pada pola penyajian EoS dan seri informasi panjang.

Pembahasan hasil pengujian yang terakhir yakni, H4 pada penelitian ini dinyatakan ditolak dengan nilai probabilitas $0.136 \geq 0.005$ dan menimbulkan No Order Effect. Hasil ini konsisten dengan penelitian Trotman dan Wright (1996), Ashton dan Kennedy (2002), dan Pinsker (2007) yang menyatakan No Order Effect terjadi pada pola penyajian $E o S$ dan seri informasi pendek.

Kesimpulan dari pembahasan ini yaitu metode yang efektif digunakan untuk pengambilan keputusan investasi berdasarkan Model Belief Adjustment yaitu pola penyajian end of sequence dan seri informasi pendek, dikarenakan pada pola penyajian EoS investor dapat mereview keseluruhan informasi pada saat itu juga. Sehingga, investor tidak dapat melakukan penyesuaian yang berlebihan dan akan berdampak pada kualitas keputusan yang diambil.

Hasil penelitian ini menunjukkan bahwa revisi keyakinan yang dikemukakan oleh Hogarth dan Einhorn (1992) adalah partially hold dalam pengambilan keputusan investasi. Prediksi revisi keyakinan yang dikemukakan oleh Hogarth dan Einhorn (1992) yang tidak terdukung yaitu pertama, penelitian ini tidak berhasil 
memberikan dukungan bahwa pola penyajian $S b S$ pada seri informasi panjang akan menimbulkan primacy effect ketika subjek menerima informasi sederhana. Kedua, penelitian ini tidak berhasil memberikan dukungan bahwa pola penyajian $E o S$ pada seri informasi panjang maupun pendek akan menimbulkan primacy effect ketika subjek menerima informasi sederhana.

Hasil dari penelitian ini memberikan bukti bahwa kompleksitas informasi mempengaruhi dalam pengambilan keputusan investasi. Keterbatasan kognitif individu berdampak pada proses pengolahan informasi yang diterimanya. Informasi yang diberikan terlalu panjang, berdampak pada investor tidak mampu menyerap keseluruhan dari informasi yang diterimanya. Namun, apabila informasi yang disajikan cukup ringkas maka individu akan mudah menyerap informasi yang diterimanya. Bentuk pengungkapan informasi yang paling efektif dan efisien yang memudahkan investor adalah financial highlights, yaitu ringkasan kinerja keuangan perusahaan yang penting.

Pada penelitian ini juga membuktikan bahwa keterbatasan individu untuk mencerna informasi nonakuntansi yang bersifat data kualitatif. Salah satu argumentasi ini yaitu investor lebih mudah untuk membandingkan dengan pengukuran umum dikarenakan memiliki skala yang sama. Hal tersebut memungkinkan investor untuk mengevaluasi secara langsung untuk setiap alternatif, sedangkan untuk membandingkan pada pengukuran unik jauh lebih kompleks dikarenakan investor membutuhkan untuk mengevaluasi skala absolut untuk setiap pengukuran unik, supaya memungkinkan mengevaluasi kinerja pada setiap alternatif pengukuran unik. Pernyataan tersebut didukung penelitian oleh Dilla dan Steinbart (2005) dan Lipe dan Salterio (2000) yang menyatakan bahwa investor menggunakan baik pengukuran umum (keuangan) dan pengukuran umum (nonkeuangan), tetapi lebih memberikan proporsi yang besar pada pengukuran umum (keuangan).

\section{Keterbatasan Penelitian}

Terdapat beberapa keterbatasan dalam penelitian ini yaitu sebagai berikut pertama, pada saat mencari partisipan terdapat beberapa partisipan yang mengundurkan diri dikarenakan terdapat keperluan lain yang tidak dapat ditinggalkan dalam waktu yang berdekatan dengan hari penugasan eksperimen. Kedua, banyaknya jumlah partisipan yang datang terlambat dikarenakan cuaca di lokasi penugasan sedang hujan, sehingga tidak dapat mengikuti penugasan eksperimen. Ketiga, peneliti telah menetapkan kriteria bagi partisipan dengan kriteria memiliki IPK $\geq 3.25$, akan tetapi partisipan masih banyak yang melakukan kesalahan dalam menjawab pertanyaan umum akuntansi sesuai dengan standar yang ditetapkan oleh peneliti, sehingga peneliti membuat dua alternatif standar jawaban benar yang harus dijawab oleh partisipan pada bagian pertanyaan umum akuntansi. 


\section{Saran}

Berdasarkan hasil penelitian, simpulan dan keterbatasan penelitian ini diperlukan saran untuk penelitian-penelitian selanjutnya yaitu pertama, memberikan informasi kepada partisipan bahwa batas waktu untuk mengundurkan diri adalah jauh-jauh hari atau tidak mendekati hari penugasan. Kedua, mencari partisipan cadangan, agar apabila terdapat partisipan yang datang terlambat maka masih terdapat partisipan yang menggantinya. Ketiga, menentukan kriteria nilai untuk mata kuliah yang dijadikan syarat dalam mengikuti penugasan ini. Keempat, memberikan undangan secara resmi yang dapat digunakan sebagai pengingat bahwa pada hari yang sudah ditentukan partisipan menghadiri penugasan eksperimen. Kelima, sebaiknya peneliti mengingatkan partisipan dengan cara menghubungi partisipa secara berkala agar partisipan tidak datang terlambat.

\section{DAFTAR PUSTAKA}

Almilia, L. S, J. Hartono, Supriyadi, dan E. Nahartyo. 2013. "Belief adjustment model in investment decision making." Gadjah Mada International Journal of Business 15 (2): 1-12.

Almilia, L. S, dan Supriyadi. 2013. "Examining belief adjustment model on investment decision making." International Journal of Economics and Accounting 4 (2): 169-83.

Almilia, L. S, dan P. Wulanditya. 2016. "The effect of overconfidence and experience on belief adjustment model in investment judgment." International Research Journal of Business Studies 9 (1): 39-47.

Alvia, L., dan D. Sulistiwan. 2009. "'Pengujian efek resensi dan pengetahuan pada penyajian informasi analisis fundamental \& teknis: studi eksperimen pada pengambilan keputusan investasi saham."”

Ananda, T. I. A, dan I. Utami. 2014. "Urutan, cara, dan bentuk informasi: Pengujian eksperimental efek resensi dan keputusan audit." In Prosiding Simposium Nasional Akuntansi XVII, 1-20.

Ashton, A. H, dan R. H. Ashton. 1988. "Sequential belief revision in auditing." The Accounting Review 64 (4): 623-641.

Ashton, R. H, dan J. Kennedy. 2002. "Eliminating recency with self review: The case of auditors 'going concern' judgments." Journal of Behavioral Decision Making 15: 221-31.

Dilla, W. N, dan P. J. Steinbart. 2005. "Relative weighting of common and unique balanced scorecard measures by knowledgeable decision makers." Behavioral Research in Accounting 17: 43-53. 
Hogarth, R. M, dan H. J. Einhorn. 1992. "Order effect in belief updating: The belief - adjustment model." Cognitive Psychology 24: 1-55.

Kusumawardhani, H., dan L. S. Almilia. 2015. "Pola penyajian informasi dan keputusan investor yang irasional.” Jurnal Bisnis dan Ekonomi 22 (2): 14053.

Lipe, M. G., dan S. E. Salterio. 2000. "The balanced scorecard: judgmental effects of common and unique performance measures." The Accounting Review 75 (3): $283-298$.

Nahartyo, Ertambang. 2012. Desain dan implementasi riset eksperimen. Yogyakarta: UPP STIM YKPN.

Pinsker, R. 2007. "Long series of information and nonprofessional investors belief revision." Behavioral Research in Accounting 19: 197-214.

- 2011. "Primacy or recency? a study of order effects when nonprofessional investors are provided a long series of disclosures." Behavioral Research in Accounting 23 (1): 161-83.

Pravitasari, N. P., dan L. S. Almilia. 2015. "Pengaruh pola penyajian end of sequence dan seri informasi pendek dalam pengambilan keputusan investasi." Jurnal Bisnis dan Ekonomi 22 (2): 129-39.

Trotman, K. T., dan A. Wright. 1996. "Recency effect: Task complexity, decision mode, and task - specific experience." Behavioral Research in Accounting 8: $175-193$.

Wahyuni, S, dan J. Hartono. 2012. "Reminder effect and anchoring-adjustment in earnings announcement: Implementation of prior-period benchmark disclosure strategy"." Journal of Indonesian Economy \& Business 27 (3): 390-405. 
